\title{
Disease and the Christian Discourse of Jewish Death in De Excidio Hierosolymitano 5, 2
}

The late fourth-century text called Pseudo-Hegesippus, or On the Destruction of Jerusalem (De Excidio Hierosolymitano) ${ }^{2}$, articulates one of the most forceful iterations of the late antique Christian historical perspective that saw the Jews as having been effectively erased from history in the first century CE or shortly thereafter. By the later fourth century this outlook had been developing within Christian circles for hundreds of years. Such a notion was theological, historical, and ideological, and it recognized a historical progression wherein (1) God sent his Son as savior to the Jews, (2) the Jews rejected and crucified their would-be messiah Jesus, and there-

1 Dr Carson Bay, University of Bern, Switzerland, Postdoctoral Researcher, Institute for Jewish Studies; email: carson.bay@theol.unibe.ch; ORCID: 0000-0003-1364-182X.

2 The text of De Excidio in this article is taken from the standard critical edition of V. Ussani (Hegesippi qui dicitur Historiae libri v-Pt. 1: Textum criticum continens, CSEL 66/1, Vindobonae 1932); all translations are my own. One of the best introductions to De Excidio, and the only proper monograph on the work to date, is C. Somenzi, Egesippo Ambrogio: Formazione scolastica e Cristiana a Roma alla metà del IV secolo, SPM 27, Milan 2009. More briefly see A.A. Bell, Josephus and Pseudo-Hegesippus, in: Josephus, Judaism, and Christianity, ed. L.H. Feldman - G. Hata, Detroit 1987, p. 349-361; Bell has done the most important preliminary work on the text to date. De Excidio can be reasonably dated between 350 and $430 \mathrm{CE}$, but it is usually ceded that it was written c. 370-375, though not by L. Van Hoof - P. Van Nuffelen, The Fragmentary Latin Histories of Late Antiquity (AD 300-620): Edition, Translation and Commentary, Cambridge 2020, p. 78. The author is colloquially referred to as "Pseudo-Hegesippus", though it has often been ascribed to Ambrose, and less frequently to other authors. The text has been assumed to have been from Italy, perhaps Rome, but is in my opinion, following Bell, most likely a product of Antioch (or at least its author was). See C. Bay, Pseudo-Hegesippus at Antioch? Testing a Hypothesis for the Provenance of the "De Excidio Hierosolymitano", BABELAO 8 (2019) p. 97-128. 
fore (3) God not only disowned his former people but actively erased them from history (more or less). This erasure came to be identified by some with the Roman destruction of Jerusalem and its Temple in $70 \mathrm{CE}$, the defining event of the Roman-Jewish War (66-73 CE) ${ }^{3}$. Paradigmatic of this perspective is the historical vision cast by De Excidio, a rewrite of Flavius Josephus' seven-book, Greek Jewish War (written in the later first-century $\mathrm{CE}$ ) into a five-book, Latin Christian work.

De Excidio, which joins Josephus in resembling the classical GrecoRoman historiographical tradition far more than any other ancient Christian historiography ${ }^{4}$, is a work expressly about the causes, details, meanings, and consequences of Jerusalem's destruction, as its title suggests. Scholars have recognized the broad contours of the text's "anti-Jewish" tone and perspective ${ }^{5}$ : Ps-Hegesippus stereotypes and denigrates the Jews, blames them for their own fate (drawing upon but far outstripping ideas found in Josephus' Jewish War), and paints them as a morally bankrupt and divinely abandoned gens. In essence, this constitutes a Christian discourse of Jewish death: it is a Christian conceptualization and projection of how the Jews "died" as a people when the Romans destroyed them in the first century. When I speak of a "discourse of death" in De Excidio, this is what I mean: an interconnected web of intratextual arguments, allusions, metaphors, and descriptions designed to help frame, explain, and depict how the Jews,

3 See P. Perkins, If Jerusalem Stood: The Destruction of Jerusalem and Christian Anti-Judaism, BibInt 8 (2000) p. 194-204. Other historical 'options' for Christians looking to identify an endpoint in Jewish history included the Bar-Kochba revolt of the early second century, which Justin Martyr and Eusebius use to ground such a polemic; see R.A. Clements, Epilogue: 70 CE After 135 CE - The Making of a Watershed?, in: Was 70 CE a Watershed in Jewish History? On Jews and Judaism before and after the Destruction of the Second Temple, ed. D.R. Schwartz - Z. Weiss, AJEC 78, Leiden 2012, p. 517-536.

4 C. Bay, Pseudo-Hegesippus and the Beginnings of Christian Historiography in Late Antiquity, "Studia Patristica" (forthcoming); M. Sehlmeyer, Geschichtsbilder für Pagane und Christen: Res Romanae in den spätantiken Breviarien, BzA 272, Berlin 2009, p. 88-89, 196-197, 202, 293-294; D. Estève, L'Oeuvre historique du Pseudo-Hegésippe: “De Bello iudaico", livre I à IV, ELP 10, Université Paris Nanterre, Paris 1987 (PhD Dissertation).

5 See R.M. Pollard, The De Excidio of 'Hegesippus' and the Reception of Josephus in the Early Middle Ages, "Viator" 46 (2015) p. 65-100; Somenzi, Egesippo - Ambrogio, p. 151-182; Bell, Josephus and Pseudo-Hegesippus; Estève, L'Oeuvre historique du Pseudo-Hegésippe, p. 448-452; H. Schreckenberg, Die christliche Adversus-JudaeosTexte und ihr literarisches und historisches Umfeld (1. - 11. Jh.), EH 23/172, Frankfurt am Main 1982, p. 310-311. 
once "alive" as the people of God, came to be a "dead" people (replaced, of course, by the new people of God: the Christians).

While the basic anti-Jewish orientation of De Excidio is now a commonly-recognized feature of the work (at least for those few scholars aware of the work), exactly how this discourse functions in De Excidio - what forms it takes, where it appears, what its defining features are - has yet to be closely examined. This article takes a step in that direction by exploring one of the most interesting, and arguably one of the most important, aspects of De Excidio's discourse of Jewish death: its use of the metaphorical complex of sickness, disease, and plague to portray the first-century Jews as infected and contagious, a people approaching death and to be avoided, quarantined.

To show that and how Ps-Hegesippus does this, I isolate one key passage that appears as a constellation of the various aspects of De Excidio's disease discourse. Taking in turn some of the core concepts and vocabulary of that passage as a base, each of the following sections branches out into De Excidio as an entire work. This approach shows that Ps-Hegesippus' anti-Jewish disease discourse courses through the entirety of his history and then crystallizes into denser clusters within one integral passage. This passage comes at the 'beginning of the end' of De Excidio, as it were, right near the start of the fifth book of this five-book work.

De Excidio 5, 2 is arguably the most important, and is certainly one of the most interesting, passages in the entire work ${ }^{6}$. In it Ps-Hegesippus expands at length on a short address he found in his source, Josephus' Jewish War $(5,19-20)$. In the latter, Josephus qua author-narrator addresses Jerusalem as a city, lamenting its fall and briefly reflecting upon its causes. In PsHegesippus' version, what was a several-line passage in the original Greek balloons into an extremely long address (1350 Latin words) to Jerusalem and by proxy to the Jewish people it represents. In this one speech, given just as De Excidio begins its final plunge into a drawn-out and detailed description of Jerusalem's destruction (i.e., Book 5), Ps-Hegesippus distills the major themes of his work: the prophetic inevitability and irreversibility of Jerusalem's destruction; the Jews' depravity and moral decline; the relationship between Jesus' rejection and execution and the fall of Jerusalem/ demise of the Jews; the Romans' essential innocence in this; the ethical contrast between the virtuous ancient Hebrews and the more recent, less

6 So argues C. Bay, The Bible, the Classics, and the Jews in Pseudo-Hegesippus: A Literary Analysis of the Fourth-Century De Excidio Hierosolymitano 5.2, Florida State University, Tallahassee 2018 (PhD Dissertation). 
virtuous Jews; the importance of the Bible for interpreting later historical events. The speech revolves around explaining and portraying Jerusalem's $70 \mathrm{CE}$ destruction, which, for Ps-Hegesippus, is unlike earlier destructions inasmuch as it is absolutely final. Within this speech, Ps-Hegesippus develops several ways of discussing and depicting the death of the Jews, among which are several overlapping (figurative and literal) discourses of sickness and disease. This study argues, therefore, that De Excidio 5, 2 epitomizes Ps-Hegesippus' overarching discourse of Jewish disease. Each of the following sections begins with a key portion of the address in De Excidio 5, 2 which highlights an aspect of Ps-Hegesippus' rhetoric of Jewish contagion. We then see how each of these aspects reflect ideas which may be traced across De Excidio writ large, and how these discursive features draw upon precedents in the biblical and classical literary traditions. Finally, we will see that Ps-Hegesippus has many things in common with other $4^{\text {th }}$ - and $5^{\text {th }}$-century Christian authors who talk about Jews as 'diseased' and/or 'contagious', but also that he exhibits a distinctive configuration of this discourse that sets De Excidio apart within the milieu of late antique Christian literature.

\section{Aaron \& Numbers $16: 48$}

Near the beginning of the address at De Excidio 5, 2, 1 the author-narrator calls (or conjures) five biblical figures as a group of witnesses to "look at" (with aspice or uide) the Jerusalem he is describing and addressing $^{7}$. As Ps-Hegesippus calls each figure - Moses, Aaron, Joshua, David, Elisha - he mentions a biblical episode which is definitive of that character within the tradition. This juxtaposes these noble, ancient Hebrew heroes to their less-than-noble, latter-day descendants, the Jews. Thus, when summoning Moses Ps-Hegesippus recalls the miracles of the Exodus from Egypt, with Joshua he mentions the fall of Jericho, with David the writing of psalms, with Elisha the miraculous defeat of the Arameans. This is how Ps-Hegesippus there conjures Aaron:

Arise, Aaron, you who once, when death was devouring the majority of the people because they had offended the omnipotent God, stood between the

7 More fully on this portion of the passage see C. Bay, Jewish National Decline and Biblical Figures as Classical Exempla in Pseudo-Hegesippus: Moses, Aaron, Joshua, David, and Elisha at De Excidio 5.2.1, JBR 7 (2020) p. 167-204. 
living and the dead, and death was stayed and the plague was checked by the intervention of your body, nor was it able to become a contagion among [or 'come into contact with'] the living8.

The biblical episode Ps-Hegesippus references, a scene from Numbers 16:41-50, particularly 16:48, was a favorite of his: the story appears two other times in De Excidio in the mouths of two other speakers. First, at 3, 16 Josephus' Jewish comrades mention this story within an address they make to Josephus after the Battle of Jotapata, in which they are attempting to dissuade Josephus from giving himself up to the Romans. Their argument is that suicide would be preferable to this. At one point they sandwich Aaron as an exemplum supporting their argument, in between Moses and King Saul, saying: "Where is Aaron, who stood in the middle between the living and the dead, lest death consume the surviving population with a savage disease?"'. For these first-century Jewish soldiers, Aaron's actions in Numbers 16 represent a basic battlefield virtue: the throwing of oneself between one's people and danger. Aaron's throwing himself in harm's way was laudable because it represented his willingness to die. In response, Josephus reinterprets the episode and challenges his interlocutors' reading of the moral:

Aaron stood between the living and the dead, but this was an act of virtue and not of temerity. For he did not bring death upon himself, but neither did he fear death, who repulsed it with his body and was in all things an obstacle to the serpent. Certainly I am not Aaron, but I am not inferior to him. Look! I hold up my hands! Let them strike them who will ${ }^{10}$.

Unlike his Jewish countrymen, Josephus uses the Numbers 16 story to parse between willingness to die for one's people and an unhealthy read-

8 Ps-Hegesippus, De Excidio 5, 2, 1, CSEL 66/1, 295: "Exsurge, Aaron, qui aliquando, cum propter offensam dei omnipotentis mors plurimos populi depasceretur, stetisti inter uiuentes ac mortuos, et mors stetit atque obiectu corporis tui haesit lues nec transire potuit ad contagionem uiuentium".

9 Ps-Hegesippus, De Excidio 3, 16, 1, CSEL 66/1, 211: "Vbi est Aaron, qui inter uiuos ac mortuos medius stetit, ne mors uiuentem populum saeuo contagio depasceretur?".

10 Ps-Hegesippus, De Excidio 3, 17, 1, CSEL 66/1, 215: “Aaron inter uiuos ac mortuos stetit, et hoc uirtutis est non temeritatis. Non enim mortem sibi intulit, sed mortem non timuit, qui eam corpore suo reppulit et serpenti in omnes obstaculo fuit. Non ego quidem Aaron sed tamen non degener ab eo en offero manus, feriant ut uolent". 
iness to do so. But what we should notice here is that the Numbers 16 episode is given three different meanings in the mouths of three different speakers across De Excidio.

Setting these three presentations of Numbers 16:48 in sequence, I think it is fair to see in them three contesting (and not unrealistic) interpretations of that episode. Two of these readings are imputed to first-century Jews, the third proffered by the author/narrator himself. From Ps-Hegesippus' perspective, therefore, I suggest that the two Jewish readings are realistic, and perhaps not wrong per se, but the truer (Christian) reading is that of De Excidio 5, 2. That is to say that, for Ps-Hegesippus, the most important and/or salient meaning of Numbers 16:48 (at least for his narrative) is this: Aaron represents a time in the Hebrew past when the Israelites were protected from destruction caused by plague or disease - which even then was a result of disobedience to God - by the effective mediation of a noble and pious high priest. A broader look at the remainder of the address in $D e$ Excidio 5, 2 reveals why Ps-Hegesippus mentions Aaron in this context at the speech's beginning. As with the other Hebrew heroes who appear as the address of that chapter begins, Aaron stands as a stark and damning juxtaposition to the descendants of the Hebrews, the Jews of the first century, the subjects, objects, and addressees of that speech.

That Aaron's example sheds negative light on the Jews of De Excidio's narrative is both strongly suggested, and at one point explicitly stated, within the speech of 5, 2 itself. A little way through the speech, the narrator charges Jerusalem with sacrilegious violence:

Ananus and Jesus - chief priests - lay unburied within you, and these men who not long ago were clothed in priestly robes, who were held in honor even by foreigners, lay with deformed corpses, fodder for birds and food for dogs, with their limbs removed and scattered throughout the whole city, so that a spectacle of ancient sanctity might be seen to mourn such an affront of the sacred name and such deformity of the once brilliant office (of priest) ${ }^{11}$.

Aaron, of course, is the quintessence of the "ancient sanctity" (uetus sanctitas) whose absence in Jerusalem is now, according to Ps-Hegesippus,

11 Ps-Hegesippus, De Excidio 5, 2, 1, CSEL 66/1, 297: "Iacuerunt in te Ananus et Iesus insepulti sacerdotum principes, et illi dudum sacerdotalibus amicti stolis, qui uenerationi etiam exteris fuerant, deformi iacuerunt cadauere, escae uolatilium et deuoratio canum, membra laceri et tota dispersi urbe, ut deplorare ueteris sanctitatis species uideretur tantam sacri nominis contumeliam et speciosi quondam muneris deformitatem". 
so painfully conspicuous. In introducing Aaron's latter-day counter parts, Ananus and Jesus (not that Jesus), as dead and unburied, Ps-Hegesippus makes a thinly-veiled implication: in ancient times, the Jews' ancestors were protected from disease by a living high priest; in the narrative's present time, the Jews have lost this protection: their priests are dead. The suggestion of these parallel presentations of Aaron and Ananus-and-Jesus becomes less implicit when Aaron's name comes up again:

And previously the priestly staff blossomed even though cut off from its wooden root, but now faith withers and piety has been buried and all emulation of virtue is departed. It is no wonder if a people which has turned away from God and follows after the vile spirit of opposition has been divided against itself $^{12}$.

The reference here is to the chapter in Numbers following the episode in 16:48 mentioned above: Numbers 17 tells the story of how Aaron and a number of challengers to his authority (chiefs among the Israelites) place their respective rods or staffs outside of the Tabernacle in a divinely-ordain competition to reveal whose authority has been sanctioned by God. The rods are left overnight. In the morning, Aaron's rod (and that of the house of Levi) has budded, proof positive of his claim to legitimate priestly leadership. Ps-Hegesippus explains exactly what it means that, whereas Aaron's staff budded in ancient times, the Jews of his narrative present lack those things which it represented: fides, pietas, and uirtus, for example. Instead, the Jews "are divided" (diuisus est) and "follow a vile spirit of contradiction" (improbum contradictionis spiritum sequitur). This sedition, in fact, is one of the major forms of Jewish disease according to Ps-Hegesippus. Here we must return to Ananus and Jesus.

Ananus' and Jesus' deaths are connected to disease and sickness among the Jews in several ways. For one thing, their unburied bodies, joined by many others, are said to have caused a physical, biological epidemic among the inhabitants of Jerusalem:

Therefore in the Temple itself, in place of sweet-smelling ointments, in place of pleasantly-wafting censers, in place of the deep fragrances of various flo-

12 Ps-Hegesippus, De Excidio 5, 2, 1, CSEL 66/1, 298: "Ante et uirga sacerdotalis floruit recisa de siluestri radice, nunc et fides aret et sepulta est pietas et abiit omnis uirtutis aemulatio. Nec mirum si populus, qui a deo recessit et improbum contradictionis spiritum sequitur, in se ipsum diuisus est”. 
wers, there was the pollutant of unburied corpses, which rain had dispersed, which flames had scorched, which the sun had warmed. All the limbs of the slain citizens corrupted everything with a pungent stench. Here the putrefaction of decaying entrails, there the scent of burning overwhelmed the senses and filled the mouths of the living, so that they themselves, not much later, were consumed by a very severe disease and bewailed the fact that they were survivors ${ }^{13}$.

So we see that De Excidio's discourse of Jewish disease has a medical component, one in which Aaron is indirectly implicated: the Jews in Jerusalem were "consumed" (consumor) by a "very severe disease" (grauior morbus) which is more or less directly related to the blinding absence of the high priest(s). Later we read that those who would bury the dead are absent, having died themselves, and then that "a fury has been transferred from the dead into those who are still living" (a mortuis in eos qui adhuc uiuerent furor transferebatur), another reference to the living becoming sick via contact with dead bodies. But there is also another 'disease' among the Jews of Jerusalem according to Ps-Hegesippus, one which we caught a glimpse of above. It is the sickness of sedition, the contagion of civil unrest, and it is arguably the more serious disease that Ps-Hegesippus identifies among the Jews of first-century Jerusalem.

\section{Sedition as Disease}

In addition to the physiological epidemic within Jerusalem, the speech of De Excidio 5, 2 also describes a metaphorical disease with which PsHegesippus diagnoses the Jews of $70 \mathrm{CE}$ Jerusalem. This disease is civil insurrection: its symptoms are self-destructive behavior within the social body, its pathogens the ideologies that drive such action. This metaphor of 'civil insurrection is disease' is one that Ps-Hegesippus found in his major source, Josephus' Jewish War, which often speaks of Jewish factionalists

13 Ps-Hegesippus, De Excidio 5, 2, 1, CSEL 66/1, 299: "In templo igitur ipso pro unguentis bene olentibus, pro thymiamateriis bene spirantibus, pro diuersorum florum odoribus grauis erat insepultorum cadauerum faetor, quos pluuia dissoluerat, quos flamma ambusserat, quos sol calefecerat. Omnes artus caesorum ciuium dirum odorem faetebant. Hinc resolutorum putredo uiscerum, inde exustorum nidor sensus omnes atque ora complebant uiuentium, ut ipsi non multo post grauiore morbo consumerentur ac se superstites ingemescerent". 
and the rebellious uprisings of Jewish factionalism in terms of "disease" $(\text { vó } \sigma o \varsigma)^{14}$. As we will see, however, Ps-Hegesippus' discourse of Jewish sedition as disease goes much further.

The 'sedition-is-disease' facet of Ps-Hegesippus' Jewish-disease discourse plays upon De Excidio's propensity to personify and anatomize the city of Jerusalem. In this Ps-Hegesippus had a model in Lucan, who had earlier so presented the city of Rome in his Bellum Civile (or Pharsalia), as Martin Dinter has shown ${ }^{15}$. (It may not be coincidental that Ps-Hegesippus knew Lucan $)^{16}$. One of the more graphic corporeal portrayals of Jerusalem comes at De Excidio 5, 1, right before the address we are examining. At 5, 1, 5 Ps-Hegesippus describes the city as having its "tendons cut" (nerui succidebantur); in 5, 2, 1 he will charge Jerusalem saying, "you destroyed your ramparts with your own hands, you cut into your innards with your own swords" (cum ipsa tuis minibus destrueres munimina tua, cum tuis mucronibus foderes uiscera tua). In De Excidio 5, 2, Jerusalem is a sick body.

That sedition is the diagnosis of Jerusalem's sickness becomes clear in an odd statement Ps-Hegesippus makes to Jerusalem. After the accusation that "you were bringing voluntary betrayal against your very self" (ipsa tibi inferres uoluntariam proditionem), he continues: "It was for this reason that the Romans preferred to be spectators rather than destroyers, lest placing a hand upon your innards be perceived as more a matter of contagion than of strength"17.

The Latin term manus (here manum) is well-known to have semantic span stretching from human body-part ("hand") to military group ("force"). What is unusual here is the use of contagio to modify manus: a "contagious force" or "contagious cadre". The implication here is that the Romans at times during their siege of Jerusalem refrained from making onslaughts since the Jews were busy fighting amongst themselves - a sound military strategy. What reference to a manus contagionis does is insinuate the fur-

14 See Josephus Bellum Judaicum 2, 11, 264; 3, 443; 4, 376; 6, 337; 7, 437.

15 M. Dinter, Anatomizing Civil War: Studies in Lucan's Epic Technique, Ann Arbor 2012.

16 A.A. Bell, An Historiographical Analysis of the De Excidio Hierosolymitano of Pseudo-Hegesippus, University of North Carolina at Chapel Hill 1977, p. 98-99 (PhD Dissertation), who says that Ps-Hegesippus" "knowledge of Lucan is indisputable".

17 Ps-Hegesippus, De Excidio 5, 2, 1, CSEL 66/1, 299: "Et ideo spectatores malebant esse Romani quam percussores, ne furentibus tuis inter se uisceribus manum admouere contagionis magis quam fortitudinis aestimaretur". 
ther idea that the Romans remained at a distance for fear that they might 'catch' something. In the next section we will return to this Roman notion as it crops up elsewhere in De Excidio. For now, we must clarify exactly what it was that, according to Ps-Hegesippus, the Roman destroyers of Jerusalem thought they might 'catch' from the Jews.

As in Josephus' earlier account of the war, De Excidio identifies three ringleaders among the insurrectionary Jewish factions who more than anyone else fueled Judean revolt against Rome and civil war. These are Simon bar Giora, Eleazar ben Yair, and John of Gischala. Ps-Hegesippus describes John's migration from his native Galilean region into Jerusalem in terms of a plague infecting others:

Fleeing the regions of Galilee, as we explained above, John betook himself to the city of Jerusalem and, as if some kind of disease, he infected the minds of many, who, leaders of the scoundrels from diverse regions, had come together there even as in a cesspool ${ }^{18}$.

Not insignificantly, Ps-Hegesippus follows this description with the statement that "this was the cause of the destruction of that great city" (hoc enim illi urbi maioris causa excidii fuit). John, the pestis ${ }^{19}$ who infected (infecit) Jerusalem by means of its inhabitants (who in this case appear as individual cells of a larger body, as it were) was a causal factor in Jerusalem's destruction. A few chapters earlier Ps-Hegesippus had introduced John as "a plague indigenous to the populace" of Gischala (indigena populi lues $)^{20}$. He goes on to call him a "pestilential man" (pestilens uir) ${ }^{21}$, though the accusative form in which this identification occurs - pestilentem uirum - comes very close to calling John a virus (uirus), as opposed to a man (uir). Ps-Hegesippus was likely playing on the ambiguity. All of this shows that John of Gischala, one of the main rebel factionalists responsible for the Jewish revolt against Rome and Jewish infighting (according to

18 Ps-Hegesippus, De Excidio 4, 6, 1, CSEL 66/1, 247: "Fugiens ut supra diximus, de Galilaeae partibus Iohannes ad Hierosolymitanam urbem se contulit et quasi quaedam pestis infecit animos conplurium, qui ex diuersis regionibus principes flagitiorum eo quasi in sentinam confluxerant”. Cf. Josephus, Bellum Judaicum 4, 122.

19 Cf. Ps-Hegesippus, De Excidio 4, 4, 6.

20 It is interesting that this is one of only two places where the nominative lues appears in De Excidio; the other is in the introduction of Aaron vis-à-vis Numbers 16:48 at De Excidio 5, 2, 1.

21 Ps-Hegesippus, De Excidio 4, 4, 5, CSEL 66/1, 246. 
Ps-Hegesippus, as well as Josephus), is a major factor in Jerusalem's 'sickness' according to De Excidio. He is representative of the kind of disease the Jews have.

John, however, was not alone in suffering from the sickness of sedition. Very early on in De Excidio one finds the same kind of plague (pestis) being attributed to the Jews as a whole. While relating the reign of Alexander Janneus (103-76 BCE), not the best-loved Judean king of all time, Ps-Hegesippus marks how Alexander was successful on the battlefield, but that "A domestic rebellion interrupted these successes in war, and the dispute, having arisen in social gatherings, advanced to war by a plague of the sort familiar to the men of the Jews, that they stir themselves to arms from sympotic play"22. The kind of plague that John is said to be, as it turns out, is an affliction characteristic of the Jews as a whole. Domestica seditio and contentio are pockmarks of Jewish social behavior, according to Ps-Hegesippus. Thus at many places in De Excidio's narrative we find manifestations of this disease emerging. For example, at De Excidio 3, 22, 1 we read that in Tiberias "the common people had been fermenting among themselves with the serious disease of dissension" (ipsa graui morbo dissidentis inter se plebis exaestuabat ${ }^{23}$. This prompts Vespasian to restore health (sanitas) to the region by means of the "cure" (remedium) of military quashing. Below we will find that this idea of a remedy finds a more forceful expression in De Excidio 5, 2. For now all we need recognize is that rebellion and civil discord is portrayed as a disease of the Jews throughout De Excidio, not just in one or two sections.

This thoroughgoing discourse of Jewish dissension as disease reaches its apogee in De Excidio 5, 2, where the Jews' destruction within Jerusalem, both self-wrought and elicited from the Romans, is most graphically and dramatically depicted. Early on in the address we read:

Therefore rebellion holds sway within you, peace has been buried, so that you perish at your own hands more cruelly than if you were to perish at the hands of others. How much has the Roman done to you with his weapons, you wretched city, compared to what evils your own populace has introduced? As you contended with the Romans, they have done so with you. The Romans desired peace, you have declared war. What cause was there that you should

22 Ps-Hegesippus, De Excidio 1, 9, 3, CSEL 66/1, 13: "Hos bellandi successus domestica seditio interpolauit, et orta conuiuiis usque ad bellum contentio processit familiari peste huiusmodi Iudaeorum uiris, ut de epulari ludo sese in arma excitant".

23 Ps-Hegesippus, De Excidio 3, 22, 1, CSEL 66/1, 226. 
provoke those stronger than you? Doubtless it was a hard thing that a gentile entered the temple against the sacred law, but already it was not the temple of God. You were not the city of God, nor were you able to be, because you were a tomb of the dead, particularly of those of your own people whom you yourself killed, and not those dropped by the enemy. For could you have been the house of life, who were the home of death, a lodging-place of wickedness, a cave of bandits? ${ }^{24}$

Here Ps-Hegesippus plays explicitly on the trade-off between the Jewish destruction of the Jews and the Roman destruction of the Jews. And again, this self-destruction is indicative of plague, parallel to the lues which Aaron had once prevented from touching the people of Israel; it is also contagious, as we saw when Ps-Hegesippus stated that the Romans aggressors sought to avoid the contagio among the Jews of Jerusalem. Having established that the sedition-as-disease discourse of De Excidio 5, 2 does in fact represent a metaphor present throughout the work, we now turn back to the idea of the contagiousness of this disease, especially as perceived by the Romans within De Excidio's narrative.

\section{The Romans and Jewish Contagion}

Above we saw in De Excidio 5, 2 that Ps-Hegesippus imagined the Romans as having kept back from their assault upon Jerusalem at times for fear of contracting something that the Jews had. What they had was a proclivity for rebellion and infighting. And while De Excidio 5, 2 is the first place in the work where we come across this idea expressed explicitly, it is not the last.

The most outright and most forceful expression of the idea that the Jews' disease of insurrection was contagious is put into the mouth of the

24 Ps-Hegesippus, De Excidio 5, 2, 1, CSEL 66/1, 297: "Ideo in te regnat seditio, pax sepulta est, ut crudelius a tuis pereas quam si ab alienis perires. Quid tantum tibi, miserabilis ciuitas, Romanus suis armis, quantum populus tuus malorum inuexit? Vt Romanis pugnares, tui fecerunt. Pacem uolebant Romani, tu bellum indixisti. Quid causae erat ut fortiores lacesseres? Durum sane quod contra legem sacram templum gentilis intrauit, sed iam non erat dei templum. Non eras dei ciuitas, nec esse poteras, quia eras mortuorum sepulchrum et praesertim tuorum quos ipsa occideras, non quos ab hoste amiseras. Quomodo enim poteras uitae esse domicilium, quae eras mortis habitaculum, deuorsorium scelerum, latronum speleum?". 
Roman general Titus. At De Excidio 5, 40, one encounters a horrific episode in which a woman, besieged and bereft within Jerusalem, kills, cooks, and eats her own infant son in a bout of insanity (cf. Josephus War 6, 199213). At De Excidio 5, 41, Titus hears report of this deed. Here is a selection of the things he says in response to this news:

Upon hearing this [news of Maria's deed], Caesar cursed the contagion of the unhappy country and, lifting his hands to heaven, declared as follows: "[...] I, blameless, declare myself innocent before you from this contagion, whatever power you are who exists in heaven. [...] May their own ruins cover it and hide it, lest the sun look upon the disease of the earth itself, lest the sphere of stars behold it; lest the breeze of the wind be defiled, and that cleansing fire arise" ${ }^{\prime 25}$.

For Titus, the Jews' disease is contagious. But notice the terms in which that contagiousness is described: what Titus curses, disavows, and plans to eradicate is a disease whose contraction has ritual/religious/theological implications, as well as geographical and meteorological ones. Titus absolves himself from contact with Jerusalem/the Jews, and describes whatever they 'have' as an infection of the world itself, affecting even the air and ground. Importantly, this speech acts more or less as a justification and explication of Titus' plan to destroy Jerusalem: it cannot be allowed to survive. This correlates with what we saw earlier when Ps-Hegesippus called John of Gischala's pestilential influence within Jerusalem the causa of Jerusalem's excidium. Remember that De Excidio is a work whose explicit topic of concentration is Jerusalem's destruction: to link that destruction directly to a Jewish contagion renders the discourse of Jewish disease one of the more important figurative constructions of the work.

Not only the allusion to Aaron and Numbers 16:48, nor only the presentation of sedition as a disease (and thus Jerusalem as a diseased body), but also the portrayal of Jewish civil sickness as a contagion finds one of its paradigmatic expressions in De Excidio 5, 2. By looking elsewhere in

25 Ps-Hegesippus, De Excidio 5, 41, 2, CSEL 66.1: 387: “Quo conperto Caesar exsecratus infelicis terrae contagium, manus ad caelum eleuans, talia protestabatur: «[...] Mundus ego ab hoc contagio tibi me absoluo, quaecumque in caelo potestas es. [...] Operiant eam ruinae suae atque abscondant, mundi ipsius contagionem ne sol uideat, ne stellarum globus spectet; ne maculentur aurarum spiramina, purgatorius quoque ille exsurgat ignis»»". Titus' self-absolution may be a nod to Pilate's parallel statement in Matt 27,24 ; my thanks to the anonymous reviewer for pointing this out to me. 
the work, in this case De Excidio 5, 41, 2, we also see again that the aspects of Ps-Hegesippus' disease discourse contained in De Excidio 5, 2 are representative of broader themes which span the work. One final feature of Ps-Hegesippus' discourse of Jewish disease, arguably its crowning feature, is given forcefully in De Excidio 5, 2, and yet again may be traced to more remote regions of the narrative.

\section{Jesus as Cure \& the Theology of Jewish Disease}

The multifarious disease that Ps-Hegesippus imputes to the Jews in De Excidio 5, 2, 1 is not without remedy. Indeed, Ps-Hegesippus overtly identifies the cure within that very address. Very early he asks:

What remedy is to be sought where the author of the remedy is not accepted? What did you think would happen, when with your own hands you crucified your own well-being, with your own hands extinguished your life, with your own voices banished your advocate, amid your domestic disturbances killed your ally, but that you also would turn your hands against yourself? You have that which you sought, you have snatched from yourself the Prince of Peace, you have asked that the Lord of Life be put to death, to him you have preferred Barabbas, who had been sent to prison for having aroused rebellion among the people and for having committed murder. Therefore your well-being has abandoned you, peace has departed, serenity has ceased - rebellion has been bestowed upon you, destruction has been bestowed ${ }^{26}$.

Recall that in our discussion of De Excidio 3, 22 above Vespasian applied the remedium of the Roman military to revolting Judean cities like Tiberias. That, it turns out, was a kind of temporary remedy. For PsHegesippus, Jesus Christ held the ultimate cure for the Jews' maladies ${ }^{27}$.

26 Ps-Hegesippus, De Excidio 5, 2, 1, CSEL 66/1, 296: “Quod remedium quaeritur, ubi auctor remedii non reconciliatur? Quid putabas futurum, cum tuis manibus salutare tuum crucifigeres, cum tuis manibus uitam tuam extingueres, cum tuis uocibus aduocatum tuum exterminares, tuis infestationibus auxiliatorem tuum interficeres, nisi ut in te quoque tuas iniceres manus? Habes quod petisti, eripuisti tibi praesulem pacis, petisti necari uitae arbitrum, concedi tibi Barabban, qui propter seditionem factam in ciuitate et homicidium missus fuerat in carcerem. Ideo salus abs te abscessit, pax abiit, quies destitit, data est tibi seditio, datum excidium".

27 See Bay, The Bible, the Classics, and the Jews, p. 280-283. 
Inasmuch as the Jews rejected Jesus, their would-be auctor remedii, they remained uncured and, indeed, from Ps-Hegesippus' perspective, ended up dying of their illness.

It should be mentioned that the 'Jesus cure' Ps-Hegesippus mentions is not without connection to the other aspects of De Excidio's anti-Jewish disease discourse discussed so far. For example, we already saw in Titus' speech from De Excidio 5, 41, 2 that the Roman response to Jewish sedition has a theological component. This point of contact between the Jewish disease of sedition and God becomes far more pronounced in De Excidio 5, 2, however:

It is no wonder if a people which has turned away from God and follows after the vile spirit of opposition has been divided against itself. For how would he have been able to hold onto his peace who had repudiated the peace of God? Christ is the peace of God who made the two one. For this reason, from one people many have rightly been turned against themselves, because, divided, they did not want to follow Jesus, who was bringing harmony, but rather, united, they followed the divisive spirit of fury. Therefore you were receiving a just reward for your faithlessness, Jerusalem, when you destroyed your ramparts with your own hands, when you tore out your entrails with your own swords, so that the enemy had pity on you, and he spared you so that you might rage. For he saw that God fought against you and had engaged himself on behalf of the Romans, and how you were voluntarily inflicting betrayal upon yourself ${ }^{28}$.

This part of the speech immediately precedes another portion which we discussed above, that in which it is said that the Romans preferred to be spectatores to Jerusalem's destruction rather than getting involved. We saw that this had to do with the Romans recognizing a contagious sickness of sedition among the Jews. Here we see that this recognition was also

28 Ps-Hegesippus, De Excidio 5, 2, 1, CSEL 66/1, 298: "Nec mirum si populus, qui a deo recessit et improbum contradictionis spiritum sequitur, in se ipsum diuisus est. Quomodo enim pacem suam tenere poterat qui pacem dei repudiauit? Pax dei Christus est qui fecit utraque unum. Merito ergo ex uno populo plures aduersum se facti sunt, quia noluerunt sequi diuisa consociantem Iesum, sed secuti sunt coniuncta diuidentem furoris spiritum. Soluebas igitur, Hierusalem, mercedem perfidiae tuae, cum ipsa tuis manibus destrueres munimina tua, cum tuis mucronibus foderes uiscera tua, ita ut hostis misereretur, ut ille parceret tu saeuires. Videbat enim quod deus aduersum te pugnaret et Romanorum fungeretur partibus, ut ipsa tibi inferres uoluntariam proditionem”. 
associated with a divine component: the Romans, says Ps-Hegesippus, understood that God had turned against the Jews. At this point a number of the different parts of Ps-Hegesippus discourse of Jewish disease begin to make complementary sense. Aaron and the Numbers 16 story expose what the first-century Jews are lacking - priestly protection from plague - while at the same time insinuating one of the classic causes for plague among the Jews: divine chastisement. This divine punishment is now known as both the cause of the Jewish disease of sedition and a result of the Jews' rejection of Jesus, their would-be cure, both at the same time. The Romans, furthermore, recognize the divine hand in this Jewish infighting, something which they recognize as a contagious disease. De Excidio 5, 2 is the only place in the work where all of these extensions of this discourse come together, and consequently it is the place where they are most forcefully expressed.

There is, however, one other passage that should be mentioned in seeking to illustrate Ps-Hegesippus' theology of Jewish sickness. It comes in a speech given by Josephus (the narrative character) at De Excidio 5, 16. It is actually the second in a string of two speeches given by Josephus at Titus' behest to the Jews holed up inside Jerusalem. Keeping a safe distance from the walls, from which his countrymen attempt to strike him with spears and such, Josephus gives these speeches in his native tongue (patrio sermone; 5, 14, 5). During the second speech, Josephus surveys Jewish history as part of a tour de force against Jewish resistance to Rome. He argues not only that armed resistance had never worked for the Jews or their ancestors in the past, but also that the situation is hopeless due to the Jews' current state. Having become unhealthy and polluted, Josephus is made to say, God had abandoned them:

No wonder if divine favor has departed from the Jews, whom so many shameful things had walled in. For surely, a good man will flee his home and desert his house, full of horror, if he learns that some crime has been committed in it - he refuses to be associated with a dishonorable household, and he abhors the iniquities of those who abide there; and shall we doubt concerning the highest and immaculate God, that he would abhor the taint of such shameful things, and that he would turn away from such deadly crimes, lest he be delayed within the meeting places of murderers, he who commanded that Dathan and Abiram be separated from the innocent, because they had challenged Moses and Aaron for claiming the priestly office, lest either their stain 
contaminate the pious by their proximity to the guilty or their punishment engulf them? ${ }^{29}$

By this point we should be unphased when we encounter the language of contagion, contamination, and pollution in such contexts within De Excidio. What is striking in this passage is how stark a statement Josephus makes about God's abandoning the Jews. Here Ps-Hegesippus is building upon material he found already in his source - particularly Josephus' War 5, 392 and 5, 413-415 - to make a much more unequivocal statement about Jewish pollution and the divorce between God and his former people. Moreover, it is telling of Ps-Hegesippus' interpretive proclivities that once again Aaron appears here, now alongside Moses and Dathan and Abiram, as an example of what God is like and thus explanation of what is happening in the narrative. The reference, unsurprisingly, is again to Numbers 16, now to the earlier part of that chapter (Numbers 16:1-35) when Dathan and Abiram, along with Korah, rebelled against Moses' and Aaron's authority and paid the ultimate price for doing so. Moreover, it is not insignificant that in this biblical scene we find the idea of rebellion being a spreadable or 'catching' thing, hence the mandate for the innocent, non-rebelling Israelites to avoid proximity to the offenders who had been targeted for destruction. It appears that when Ps-Hegesippus thought about the rebellious faction of Israelites from Numbers 16 (and 17), he saw a compelling parallel to the Jews of 66-73 CE.

At the end of the day, De Excidio evinces a host of interrelated meanings attached to disease, sickness, and/or contagion as states of being that describe the first-century Jews of its narrative. Moreover, we find all of these meanings mixed into the speech of De Excidio 5, 2. This complex of meanings uses the metaphor 'Jerusalem is a body' or 'the Jews are a body' to depict (1) sedition as a disease/plague; (2) physiological disease as exist-

29 Ps-Hegesippus, De Excidio 5, 16, 1, CSEL 66/1, 331-332: "Nec mirum est si recessit a Iudaeis diuina gratia, quos tanta flagitia circumuallarunt. An uero bonus uir plenum horroris refugit diuersorium et domum suam deserit, si quid in ea commissum sceleris agnouerit, declinat indignae habitationis consortia, execratur conuersantium iniquitates: et dubitamus de summo et immaculato deo, quod abhorreat tantorum contagia flagitiorum, et funestorum scelerum auersetur atrocitatem, nec demoretur in parricidarum conciliabulis, qui Dathan et Abiron, quia Moysen et Aaron praeripiendo sacerdotii munere lacessiuerant, separari ab innoxiis praecepit, ne pios aut macula contaminaret de consortio noxiorum aut poena inuolueret?". This part of this speech builds upon a shorter and rather different speech in Josephus' Bellum Judaicum 5, 376-419. 
ing alongside social disease; (3) disease/plague as the result of punitive divine wrath unchecked by legitimate priestly protection; (4) both physiological and metaphorical disease as contagious; (5) disease/plague as causing ritual pollution; (6) disease/plague as directly linked to Jerusalem's and the Jews' ultimate destruction; (7) the disease/plague of sedition as something characteristic of the Jewish people; (8) Jesus Christ as the unused remedy for disease/pollution for first-century Jews; and (9) the disease/plague of sedition, which causes ritual pollution, as a reason that God had abandoned the Jews ${ }^{30}$. That number 3 and number 9 above do not logically jibe should not necessarily bother us, as consistency is not a standard feature of Christian discourse about Jews in late antiquity ${ }^{31}$. What we should note is the complexity and overlapping nature of this discourse. The fact that it all comes together in one chapter is a literary fact which in some sense speaks for itself: De Excidio 5, 2 is manifestly, I argue, the epitome of PsHegesippus' anti-Jewish disease discourse.

\section{The Bible, the Classics, \& De Excidio's Disease Discourse}

Ps-Hegesippus' discourse of Jewish disease did not emerge in a cultural vacuum. In fact, two distinct spheres of literary tradition stand behind the rhetoric of Jewish contagion that appears in De Excidio. Broadly speaking, these are the Judaeo-Christian sphere of biblical literature, and the Greco-Roman sphere of classical literature. A brief foray through these literatures reveals a rich tradition undergirding Ps-Hegesippus' disease discourse, which goes some way in helping explain where Ps-Hegesippus got inspiration for that discourse and the reasons for the terms, themes, and forms it takes on within De Excidio.

To begin with, the idea of a city (e.g., Jerusalem) or of a social group, often defined in racial/ethnic, national, and/or religious terms (e.g., the Jews), as being analogous to a human body is an idea to be found in both the biblical corpus and the classical. In biblical literature, one need look no further than the prophets to find a good store of such imagery. Perhaps most famously, Chapter 1 of the Book of Isaiah portrays the people of

30 These last two, numbers 8 and 9, may reasonably be read in conjunction as part of Ps-Hegesippus' anti-Jewish 'theology of disease' inasmuch as he identifies himself explicitly as a Trinitarian Christian, albeit only once, at De Excidio 5, 9, 4.

31 See T.S. Berzon, The Double Bind of Christianity's Judaism: Language, Law, and the Incoherence of Late Antique Discourse, JECS 23 (2015) p. 445-480. 


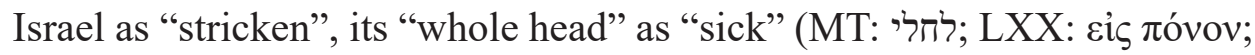
VUL: languidum) 32 , as having nothing "sound" "33 "from the sole of the foot up to the head", but "only bruises, welts and raw wounds, not pressed out or bandaged, nor softened with oil" (Isaiah 1:5-6). This bleak and graphic portrayal of Israel as a nation combines the personification and anatomization of the people with the metaphor of sickness as rebellion, and this in turn is packaged together with ideas of moral pollution and ritual impurity. In a similar vein, Jeremiah attributes "sickness and wounds" (חלי ומכה

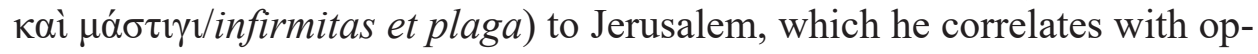
pression (Jeremiah 6:6-7); not incidentally, here Jeremiah is prophesying about a divinely-mandated siege against Jerusalem. A perusal of the prophets will reveal many such statements, and both the Old and New Testaments will have provided a Christian author like Ps-Hegesippus plenty of plague, sickness, and disease metaphors for use in socially- and demographically-oriented critique. ${ }^{34}$ The biblical tradition provided plenty of fodder for building the kind of Jewish-disease discourse which Ps-Hegesippus builds within De Excidio.

The classical literary tradition is no less imbued with these metaphors. Spencer Cole has recently discussed how first-century Romans, and before them Aristotle and Polybius (e.g.), "conceived of the nation as a living organism" and framed "its perceived enemies as disease bringers" 35 . Nowhere is such a trend more apparent than in the literary production of Cicero, who speaks of social ills, particularly civil insurrection, in terms

32 I cite the Hebrew, Greek, and Latin here because the Hebrew represents the original text (as best we can tell), the Greek the kind of text that Ps-Heg would have been reading, and the Latin a Christian rendering which is nearly contemporary to De Excidio.

33 The Hebrew for "whole/sound/healthy" here is מתם, but the Greek has a rather different, creative way of rendering "nothing sound". Here I render the whole verse, which must be taken in its dual-triplicate formula: "from feet up to head neither wound nor bruise nor injury which has swollen up has been treated with emollient or oil or ban-

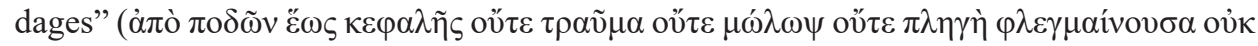

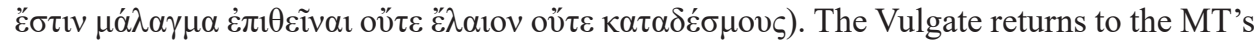
phrasing: "there is nothing soundness in it" (non est in eo sanitas), that is, in the body from food to head.

34 See Theologisches Handwörterbuch zum Alten Testament, v. 1, ed. J. Ernst C. Westermann, Gütersloh 1984, p. 567-570 (on הלח); Theologisches Wörterbuch zum

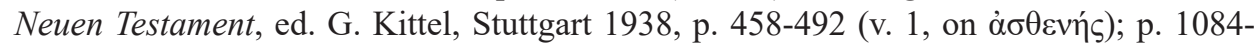
1091 (v. 4, on vóбos).

35 S.E. Cole, Metaphor and Religion in Ancient Rome, in: Theorizing “Religion” in Antiquity, ed. N.P. Roubekas, Bristol 2019, p. 224. 
of "disease" (morbus) ${ }^{36}$, and anyone who would foment such uprisings as a "disease-bringer" (pestifer). He thus dubs Marc Antony, for example ${ }^{37}$. Ilona Opelt's study on terms of abuse in classical Latin demonstrates that terms like pestis (and lues) were extremely common metaphorical insults in the work of Cicero and other authors ${ }^{38}$. The portrayal of the city in anatomical terms and the medicalization of civil war finds its most pronounced expression in Lucan's Bellum Civile (Pharsalia), which records, for example, Sulla cutting down insurrectionists like a physician performing surgery (medicina) on an outbreak of disease (morbus $)^{39}$. But many authors employed such language, especially those who, like Sallust, were writing in the wake of the culture-shifting Roman civil wars of the first century ${ }^{40}$. Moreover, it is important to note that Ps-Hegesippus knew Cicero and Lucan and Sallust and similar authors, just as he knew well the biblical tradition. In terms of Ps-Hegesippus' disease discourse, it was these paragons of classical Latinity who appear as the most prominent inspirations. Thus, when filling his notional, semantic, and lexical reservoir of contagion rhetoric, Ps-Hegesippus drew his material from a twofold - or, rather, manifold - traditionary complex.

It is unexceptional to show that De Excidio betrays influences from both biblical and classical traditions in erecting its rhetorical edifice of anti-Jewish disease discourse, but it must be shown that Ps-Hegesippus' terms and ideas had a basis in earlier tradition. Indeed, both the classical and biblical corpora had already found a fusion within Josephus' War, PsHegesippus' main source, and in some part his discourse of Jewish disease draws upon Josephus' earlier presentation of the same thing, as mentioned above. But De Excidio's iteration of this broader cultural way of thinking goes beyond biblical, classical, and Josephan accounts in its capaciousness and in its particular form. The crowning achievement of Ps-Hegesippus' anti-Jewish rhetoric of contagion is, as it were, the fusing of such a classicizing, biblically-based discourse with a Christocentric Christian theology.

36 E.g. Cicero, Sull. 76; it is highly likely that the verbiage of De Excidio's disease discourse, which also uses this term this way, draws significantly from Cicero, which would fit with the work's broader modus operandi.

37 Cicero, Philip. 5, 43; Cicero, De Dom. Sua 2.

38 I. Opelt, Die lateinischen Schimpfwörter und verwandte sprachliche Erscheinigungen, Heidelberg 1965, p. 278 and esp. p. 135-138.

39 Lucan, Bellum Civile 2, 142-143.

40 See, e.g., Sallustius, Bellum Catilinae 36, 5; Sallustius, Bellum Jugurthinum 32,4 
The effective death of the Jews in Jerusalem's destruction comes to be portrayed not only as the inevitable result of disease, but as a disease which was caused by (or did it cause?) God's chastisement, itself a correlate of Jesus' rejection and crucifixion. In line with ancient literary norms, wherein texts grounded themselves in authoritative tradition while defining and distinguishing themselves by improving upon and innovating within such tradition $^{41}$, De Excidio brings together a dense discourse packed with punchlines from a diversity of earlier sources and puts this discourse into the service of Christian anti-Judaism in the wake of nascent Christian Empire.

\section{The Christian Practice of Anti-Jewish Disease Discourse in Late Antiquity}

It should surprise no one that Ps-Hegesippus is not the only late ancient Christian author to associate the Jews with disease. Far from it. PsHegesippus wrote in a historical period and alongside other Christian writers for whom such a subject was quite usual. Yet Ps-Hegesippus' contribution to this culture-wide discourse was nevertheless quite unique, at least in its classicized generic garb if not in its precise semantic and lexical content.

The Christian author who is perhaps most famous for locating a 'disease' among the Jews is John Chrysostom. In his Discourses Against the Jews, sometimes called his Discourses Against Judaizing Christians ${ }^{42}$, Chrysostom identifies Jewish beliefs, practices, and festivals as a Jewish disease (vóбos) from which his congregants are advised to stay well away $^{43}$. This recommendation often sounds more like a mandate than a suggestion, and the risk of ignoring it like the risking of one's very soul.

41 For this norm within ancient historiography see J. Marincola, Authority and Tradition in Ancient Historiography, Cambridge 1997. For this norm within late antique Christian literature as it transformed classical literary genres, see Chapter 1 ("Tradition and Innovation: The Transformation of Classical Literary Genres in Christian Late Antiquity") in K. Pollmann, The Baptized Muse: Early Christian Poetry as Cultural Authority, Oxford 2017.

42 C. Shepardson (Between Polemic and Propaganda: Evoking the Jews of FourthCentury Antioch, "Journal of the Jesus Movement in Its Jewish Setting" 2 (2015) p. 147182) discusses how "the quantity and lurid quality of the anti-Jewish and anti-Judaizing rhetoric in Chrysostom's Adversus Iudaeos homilies have continued to capture scholars' attention disproportionately to the other evidence" (p. 147-148).

43 See John Chrysostom, Adversus Iudaeos 1, 1, 4-5; 1, 4, 4; 1, 4, 8; 1, 7, 5; 1, 7, 7; $1,8,5 ; 2,1,1 ; 2,2,3 ; 2,3,6 ; 3,1,1$ (final line); 3, 1, 4; 3, 2, 4-5; 4, 3, 5; 4, 7, 10; 8, 3, 5; $8,7,9 ; 8,7,11-12 ; 8,8,4$. 
For Chrysostom, the Jews of late antique Antioch - where these sermons were given in 386-387 CE - were highly contagious. And Chrysostom, styling himself the doctor, had to prevent the church from getting infected. It may be telling that Chrysostom was preaching these sermons at Antioch. If, as several scholars have suggested ${ }^{44}$, De Excidio is also the product of an Antiochene author, then we might fairly diagnose Antioch in the 370 s and 380 s as a site which witnessed an outbreak of anti-Jewish disease discourses.

Chrysostom and Ps-Hegesippus were far from alone in talking about such things. Cyril of Alexandria in his Commentary on John speaks of Jewish ignorance (i.e. lack of orthodox belief) as disease (vó $\sigma 0 \varsigma)^{45}$, much like Arnobius the Younger speaks of the morbus Iudaeorum in his Commentary on Psalm CIII ${ }^{46}$ and Augustine mentions "a contagion of malignity among the Jewish race" (contagio malignitatis in Iudaeorum gente) in one of his polemics and of a certain "disease among the Jews" (morbus in Iudaeos) in one of his Sermons ${ }^{47}$. Those familiar with Christian late antiquity will recognize the contiguity between such sentiments and the enterprise of heresiology endemic to the fourth and fifth centuries. Moreover, like Ps-Hegesippus, ancient Christian authors frequently drew their reservoir of polemical disease-discourse terms largely from the classical past, as Ilona Opelt has shown in regard to Cyprian and others ${ }^{48}$. Suffice it to say that Ps-Hegesippus was in good company when he talked about some form of Jewish disease.

While De Excidio's anti-Jewish disease discourse found ready companions within the larger fold of Christian literature of its time, it stands out in one or two regards. First, note that while John Chrysostom is talking about Jews in his own time and place, Augustine and Cyril join Ps-Hegesippus in projecting their ideas of the Jews as diseased onto people of the first century. But unlike any of these other authors, Ps-Hegesippus does not concentrate

44 Bay, Pseudo-Hegesippus At Antioch?; Bell, Pseudo-Hegesippus; Bell, Historiographical Analysis.

45 Cyrillus Alexandrinus, In Ioannem 2, 20.

46 Arnobius Minor, Commentarii in Psalmos CIII (PL 53, 478C-D).

47 Augustinus, Contra Epist. Parmen. 2, 17, 36; Augustinus, Sermones ad Populum 299a.

48 I. Opelt, Die Polemik in der christlichen lateinischen Literatur von Tertullian bis Augustin, Heidelberg 1980, e.g. at p. 221: "Cyprian hat den Metaphernkomplex erfolgreich um ein ciceronisches Bild pestis, lues usw. bereichert, das auch in der Polemik einzelner Häresien eingesetzt wird". 
his disease metaphors on Jewish unbelief and flawed religiosity; rather, he adopts the more classical model of using disease as a way of depicting sedition and civil war among the Jews. Ps-Hegesippus' interests here reflect the somewhat unusual nature of De Excidio as a Christian work. Ps-Hegesippus was, as Bell pointed out, "one of the first Christian historians and is the very first to attempt to write about a non-ecclesiastical historical topic"49. As a Christian writing a classical form of historiography ${ }^{50}$, Ps-Hegesippus, while not uninterested in Jewish doctrine and ritual, is primarily interested in the military and political machinations of the Jews. Generic form and narrative content serve as determiners of what Ps-Hegesippus' discourse of Jewish disease looks like, a discourse with several distinguishable types among late antique Christians. Ps-Hegesippus writes about the Jewish disease of sedition, not necessarily because he would not refer to Jewish doxa and praxis in such terms, but because insurrection was the type of thing that ancient historians wrote about. De Excidio is a story of war between the Jews and Romans, but also civil war, and as such its interests often mirror those of writers like Sallust (and Livy and Tacitus) ${ }^{51}$. In fact, De Excidio finds a telling and strikingly parallel precursor in Tacitus' Annales 6,7 , where the historian refers to Jewish heresy (Christianity?) as a plague (malum) which has infected (infecit) the city of Rome - is it a coincidence that Ps-Hegesippus, who knew Tacitus ${ }^{52}$, uses the same language to describe the same people? Even if so, Tacitus here shows that Ps-Hegesippus' discourse of disease as applied to the Jews in particular was already of some vintage within Latin literature by the late fourth century. (And of course, the association of Jews, particularly Jewish origins, with disease went back much further still) ${ }^{53}$. Ps-Hegesippus' discourse of Jewish disease

49 Bell, Historiographical Analysis, p. 46-47.

50 Bay, Pseudo-Hegesippus and the Beginnings of Christian Historiography.

51 See, e.g., Livy 3, 20, 8; 24, 2, 8; 24, 29, 3; Tacitus describes Christianity as a disease (malus) at Annals 15, 44.

52 See R. Bloch, Antike Vorstellungen vom Judentum: der Judenexkurs des Tacitus im Rahmen der griecisch-römischen Ethnographie, Stuttgart 2002, p. 190-192.

53 In Manetho, Hecataeus of Abdera, Lysimachus, Diodorus Siculus, and, just before Tacitus' time, Pompeius Trogus in his Philippic Histories, and then also Plutarch; see P. Schäfer, Judeophobia: Attitudes Toward the Jews in the Ancient World, Cambridge 1997, p. 15, 20, 22-23, 26-29, 32, 57-58, 74-75, 86, 88-89, 160, 163, 165-168; J.G. Gager, The Origins of Anti-Semitism: Attitudes toward Judaism in Pagan and Christian Antiquity, Oxford 1985, p. 46, 70-71. Disease discourse had long been a way among Greeks and then especially Romans to identify the alien other: see B. Isaac, The Invention of Racism in Classical Antiquity, Princeton 2004, p. 199, 385, 479. 
turns out to be one more way of viewing De Excidio as a confluence of classical and Christian interests and influences, setting it apart within a late antique Christian milieu in which it actually fits quite well.

\section{Conclusion}

Ps-Hegesippus wrote a history of the Roman-Jewish War. According to that history, the Roman destruction of Jerusalem which ended that conflict marked the effective death of the Jews in history. De Excidio brooks numerous ways of explaining and portraying that dying. Above we saw one of those ways: Ps-Hegesippus portrays the Jews as diseased, and this portrayal itself takes a number of interrelated forms. These forms expose much of De Excidio's historical logic - the guts of the narrative, as it were. We see in Ps-Hegesippus' discourse of Jewish disease his Christian perspective combining and adapting biblical and classical forms to rewrite a perspective which he found in Josephus' Jewish War. What this adds up to is a striking contribution to late antique Christian discourse, one which writes a history of the Jews for Christian purposes in part by portraying the Jews as a people with a certain kind of disease. Furthermore, this web of ideas coalesces within one particular chapter of the work: Book 5, Chapter 2. Thus it is my argument that De Excidio 5, 2 exposes and embodies the larger discourse of Jewish disease in the work, which suggests the centrality of that chapter within the work, just as the discourse of Jewish disease constitutes a central concept of the work.

\section{Disease and the Christian Discourse of Jewish Death in De Excidio Hierosolymitano 5, 2}

(summary)

The late-fourth century work called On the Destruction of Jerusalem (De Excidio Hierosolymitano), or "Pseudo-Hegesippus", records the history of the Roman-Jewish War (66-73 CE) and particularly the destruction of Jerusalem and its Temple by the Romans in $70 \mathrm{CE}$. As a Christian version of this history based largely upon Flavius Josephus' earlier Jewish War, De Excidio understands himself to be telling the story of the effective death of the Jews in history. One major aspect of this narrative, I argue, is a discourse of Jewish disease, wherein Ps-Hegesippus portrays the Jews as "sick" with the plague of civil insurrection and sedition. But this discourse goes much further as well, cutting to the very core of De Excidio's narrative logic. Here I argue that this discourse of Jewish disease finds its most powerful expression in one particular chap- 
ter of the work, Book 5, Chapter 2. I show that De Excidio 5, 2 epitomizes the work's rhetoric of Jewish contagion, which can nevertheless be traced throughout the entirety of the work.

Keywords: Christian-Jewish Relations; Pseudo-Hegesippus; De Excidio; Latin; Metaphor Theory; Disease; Contagion; Sickness; Jews; Historiography

\section{Bibliography}

\section{Sources}

Pseudo-Hegesippus, De Excidio Hierosolymitano, ed. V. Ussani, CSEL 66/1, Vienna 1932.

\section{Studies}

Bay C., Pseudo-Hegesippus and the Beginnings of Christian Historiography in Late Antiquity, "Studia Patristica" (forthcoming).

Bay C., Jewish National Decline and Biblical Figures as Classical Exempla in Pseudo-Hegesippus: Moses, Aaron, Joshua, David, and Elisha at De Excidio 5.2.1, "Journal of the Bible and Its Reception" 7 (2020) p. 167-204.

Bay C., Pseudo-Hegesippus at Antioch? Testing a Hypothesis for the Provenance of the De Excidio Hierosolymitano, "Bulletin de l'Académie Belge pour l'Étude des Langues Anciennes et Orientales" 8 (2019) p. 97-128.

Bay C., The Bible, the Classics, and the Jews in Pseudo-Hegesippus: A Literary Analysis of the Fourth-Century De Excidio Hierosolymitano 5.2, Florida State University, Tallahassee 2018 (PhD Dissertation).

Bell A.A., Jr., Josephus and Pseudo-Hegesippus, in: Josephus, Judaism, and Christianity, ed. L.H. Feldman - G. Hata, Detroit 1987, p. 349-361.

Bell A.A., Jr., An Historiographical Analysis of the De Excidio Hierosolymitano of Pseudo-Hegesippus, University of North Carolina at Chapel Hill 1977 (PhD Dissertation).

Berzon T.S., The Double Bind of Christianity's Judaism: Language, Law, and the Incoherence of Late Antique Discourse, "Journal of Early Christian Studies" 23 (2015) p. 445-480.

Bloch, R., Antike Vorstellungen vom Judentum: der Judenexkurs des Tacitus im Rahmen der griecisch-römischen Ethnographie, Stuttgart 2002.

Clements R.A., Epilogue: 70 CE After 135 CE - The Making of a Watershed?, in: Was 70 CE a Watershed in Jewish History? On Jews and Judaism before and after the Destruction of the Second Temple, ed. D.R. Schwartz - Z. Weiss, AJEC 78, Leiden 2012, p. 517-536. 
Cole S.E., Metaphor and Religion in Ancient Rome, in: Theorizing "Religion" in Antiquity, ed. N.P. Roubekas, Bristol 2019, p. 221-242.

Dinter M., Anatomizing Civil War: Studies in Lucan's Epic Technique, Ann Arbor 2012.

Estève D., L'Oeuvre historique du Pseudo-Hegésippe: “De Bello iudaico”, livre I à IV, ELP 10, Université Paris Nanterre, Paris 1987 (PhD Dissertation).

Gager J.G., The Origins of Anti-Semitism: Attitudes toward Judaism in Pagan and Christian Antiquity, Oxford 1985.

Isaac B., The Invention of Racism in Classical Antiquity, Princeton 2004.

Marincola J., Authority and Tradition in Ancient Historiography, Cambridge 1997.

Opelt I., Die lateinischen Schimpfwörter und verwandte sprachliche Erscheinigungen, Heidelberg 1965.

Opelt I., Die Polemik in der christlichen lateinischen Literatur von Tertullian bis Augustin, Heidelberg 1980.

Perkins P., If Jerusalem Stood: The Destruction of Jerusalem and Christian Anti-Judaism, "Biblical Interpretation" 8 (2000) p. 194-204.

Pollard R.M., The De Excidio of 'Hegesippus' and the Reception of Josephus in the Early Middle Ages, VIATOR 46 (2015) p. 65-100.

Pollmann K., The Baptized Muse: Early Christian Poetry as Cultural Authority, Oxford 2017.

Schäfer P., Judeophobia: Attitudes Toward the Jews in the Ancient World, Cambridge 1997.

Schreckenberg H., Die christliche Adversus-Judaeos-Texte und ihr literarisches und historisches Umfeld (1. - 11. Jh.), EH 23/172, Frankfurt am Main 1982.

Sehlmeyer M., Geschichtsbilder für Pagane und Christen: Res Romanae in den spätantiken Breviarien, BzA 272, Berlin 2009.

Shepardson C., Between Polemic and Propaganda: Evoking the Jews of Fourth-Century Antioch, "Journal of the Jesus Movement in Its Jewish Setting" 2 (2015) p. 147-182.

Somenzi C., Egesippo - Ambrogio: Formazione scolastica e Cristiana a Roma alla metà del IV secolo, SPM 27, Milan 2009.

Theologisches Handwörterbuch zum Alten Testament, v. 1-2, ed. J. Ernst - C. Westermann, Gütersloh 1984.

Theologisches Wörterbuch zum Neuen Testament, t. 1-5, ed. G. Kittel, Stuttgart 1938.

Van Hoof L. - Van Nuffelen P., The Fragmentary Latin Histories of Late Antiquity (AD 300-620): Edition, Translation and Commentary, Cambridge 2020. 